\title{
Оригінальні статті
}

УДК 616-089.193.4:616.833-001:617.57

\section{Татарчук М.М.}

Відділення відновної нейрохірургії, Інститут нейрохірургії ім. акад. А.П. Ромоданова НАМН України, Київ, Україна

\section{Повторні нейрохірургічні втручання при травмі периферичних нервів верхньої кінцівки}

Вступ. Повторні нейрохірургічні втручання - один з найменш вивчених розділів хірургії периферичних нервів.

Матеріали і методи. Проаналізовані результати лікування 135 хворих, яким проведене повторне хірургічне втручання на нервах верхніх кінцівок. Використані клініко-неврологічний, нейровізуалізуючі та нейрофізіологічні (НФ) методи дослідження, в тому числі стимуляційна електронейроміографія (ЕНМГ) та внутрішньом'язова голкова електроміографія (ЕМГ).

Результати. У 135 хворих виявлене ушкодження 156 нервів. Повторні оперативні втручання, виконан в пізні строки після першої операції, мають деякі особливості. За ступенем відновлення рухової функції хороші й задовільні результати досягнуті у 114 (84,4\%) повторно оперованих хворих. Хороший задовільний ступінь відновлення чутливості відзначений у $116(75,9 \%)$ повторно оперованих на нервових стовбурах верхньої кінцівки.

Висновки. 1. Клініко-нейрофізіологічний моніторинг процесу регенерації периферичних нервів дозволяє визначити подальшу тактику лікування.

2. Проведення повторного хірургічного лікування при травмі периферичних нервів покращує нейромоторну функцію верхньої кінцівки.

Ключові слова: травма периферичних нервів верхньої кінцівки, повторні операції, нейрофізіологічний моніторинг регенерації.

Український нейрохірургічний журнал. - 2013. - №1. - С. 55-58.

Надійшла до редакції 26.02.13. Прийнята до публікації 06.03.13.

Адреса для листування: Татарчук Михайло Михайлович, Відділення відновної нейрохірургії, Інститут нейрохірургії ім. акад. А.П. Ромоданова, вул. Платона Майбороди, 32, Київ, Україна, 04050, e-mail: MTatarchuk@ukr.net

Вступ. В останні десятиліття в хірургії периферичних нервів досягнутий значний прогрес завдяки впровадженню електрофізіології та мікронейрохірургії $[1,2]$. Проте, існують недоліки діагностики та незадовільні результати раніше проведеного хірургічного лікування, що потребує вибору оптимальних методів лікування хворого. Результати повторних операцій - це найменш вивчений розділ хірургії нервів [3, 4]. Дані літератури, присвячені аналізу віддалених результатів зшивання нервів, суперечливі. Оцінка результатів залежить від того, чи базується вона на даних неврологічного обстеження, чи на вивченні функції кінцівки, чи працездатності хворого [5]. Роботи, присвячені зазначеній темі, поодинокі, з малою кількістю клінічних спостережень. Недостатньо вивчені результати повторних операцій на нервах, зміни нервового стовбура, які виявляють під час повторної операції, техніка хірургічного зшивання нервів. Не з'ясовані показання, строки виконання, результати повторних операцій $[1,5,6]$. Питання про необхідність здійснення повторної операції на нерві вимагає детального аналізу та зіставлення даних анамнезу, клінічного огляду, нейровізуалізуючих та нейрофізіологічних (НФ) методів дослідження.

Мета дослідження: покращити найближчі та віддалені результати комплексного лікування хворих після недостатньо ефективного первинного опера- тивного втручання на периферичних нервах верхніх кінцівок.

Матеріали і методи дослідження. Проаналізовані результати лікування 135 пацієнтів, яким здійснене повторне нейрохірургічне втручання на периферичних нервах верхніх кінцівок за період 2005-2013 pp.

За віком хворі, госпіталізовані для повторного хірургічного лікування, розподілені на 6 груп. Більшість - 104 (61,12\%) хворих були віком від 21 до 40 років. Чоловіків було 114 (84,46\%), жінок - 21 (15,5\%).

Встановлено, що ступінь ушкодження нервових стовбурів верхніх кінцівок залежав від механізму травми. Різані поранення верхньої кінцівки склом відзначені у 25 (18,75\%) постраждалих, побутова та транспортна травма - відповідно у $84(62,14 \%)$ та $32(23,30 \%)$, виробнича - у 13 (9,71\%), вогнепальне поранення - у 4 (2,9\%), ятрогенні ушкодження - у $3(1,94 \%)$.

Під час обстеження хворого, госпіталізованого для повторного хірургічного лікування, ретельно збирали анамнез, вивчали попередню медичну документацію (виписку, результати обстеження), частіше хворі надавали неточну інформацію або недостовірні дані про характер попереднього хірургічного лікування. За інформацією з медичної документації, першу операцію 
на нервовому стовбурі виконували у травматологічній клініці - у 46 хворих, багатопрофільному стаціонарі - у 60, спеціалізованому - у 29 (табл. 1).

Більшість - 63 (46,7\%) хворих госпіталізовані для повторного оперативного втручання у клініку у строки від 6 до 12 міс після першої операції.

Застосовані наступні методи дослідження: клініко-неврологічний (симптоми Тінеля, Сулія, бальна оцінка сили м'язів та чутливості за шкалою Комітету з медичних досліджень - Medical Research Council Scale за R.Van der Ploid та ін.,1984); рентгенологічні та нейровізуалізуючі (рентгенографія, МРТ, МРА), НФ. НФкомплекс включав: 1) стандартну стимуляційну електронейроміографію (ЕНМГ) [6-8], 2) внутрішньом'язову голкову електронейроміографію (ЕМГ), 3)дослідження соматосенсорних викликаних потенціалів, а також інтраопераційну електродіагностику.

Результати повного передопераційного обстеження були вирішальними у визначенні показань до виконання повторної операції, з'ясовували помилки та недоліки під час попереднього лікування, а також визначали методи консервативно-відновної терапії 3 обов'язковим НФ моніторингом. За певних строків після першої операції до проведення електрофізіологічної діагностики важливим було виявлення будь-яких ознак відновлення функції, насамперед, у так званих «ключових» м'язах для ЕНМГ та ЕМГ тестування при ушкодженні нервових стовбурів верхньої кінцівки.

НФ критеріями для визначення тактики диференційованого повторного оперативного втручання були результати внутрішньом'язовї ЕМГ, проведеної за методиками, запропонованими Л.Ф. Касаткіною [7], Л.Л. Чеботарьовою [8].

У 135 хворих було ушкоджено 156 нервів, виконаний епіневральний шов 87 нервів за класичною методикою. Види повторних операцій представлені в табл. 2.

Повторне оперативне втручання, виконане в пізні строки після першої операції, має деякі особливості. 3 часом, внаслідок рубцевого переродження та зменшення еластичності волокон нерва, відбувається його вкорочення. Під час операції діастаз збільшувався через «освіження» країв нерва до отримання задовільних меж пучкової зернистості. Для усунення діастазу між кінцями нерва в усіх спостереженнях застосовували прийоми мобілізації з фіксацією кінцівки гіпсовою лонгетою у фізіологічному положенні. Оскільки одним з чинників, що обмежує мобілізацію нерва, $є$ наявність дрібних гілок, здійснювали їх субепінервальне виділення. Зменшенню довжини дефекту та натягу стовбура нерва сприяло його переміщення у нове ложе по коротшому шляху. Переміщення або переведення нерва здійснене у 18 $(11,5 \%)$ постраждалих, у яких діастаз між відрізками нерва перевищував 3 см.

Через рубцево-спайковий процес та атрофію периферійного відрізку нерва, які поглиблювались у міжопераційний період, спостерігали також невідповідність діаметра дистального й проксимального кінців нерва. За такої ситуації для максимальної герметизації лінії шва показане застосування збільшувальної техніки. Накладання швів за таких умов дещо полегшується завдяки введенню під епіневрій периферійного відрізку нерва розчину новокаїну.
Для більш точного зіставлення відрізків нерва та забезпечення міжпучкової відповідності доцільно використовувати як орієнтир на епіневрію кровоносні судини. Під час виконання мікрохірургічної операції використовували мікроскоп з збільшенням X 5-32, діаметр операційного поля відповідно від 50 до 8 мм. Застосування мікрохірургічної техніки дозволяло атравматично виконати етап зовнішнього та внутрішнього невролізу, тендолізу та ангіолізу магістральних судин.

Обов'язковим під час повторного оперативного втручання на нерві $€$ проведення інтраопераційної електродіагностики. НФ моніторинг показників регенеративного процесу, а саме, стимуляційну ЕНМГ та внутрішньом'язову ЕМГ, проводили у строки 1,3,6 та 12 міс.

Результати та їх обговорення. В дослідженні основну увагу приділяли оцінці скоротливої функції м'язів та покращенню нейро-моторних властивостей кінцівки. Відновлення рухової функції вважали хорошим за м'язової сили не менше 4 балів, зменшення вираженості або зникнення атрофії. Задовільним вважали результат при відновленні м'язової сили не менше 3 балів та збереженні атрофії м'язів. Як відсутність ефекту розцінювали відновлення м'язової сили на 1-2 бали (табл. 3)

Відновлення чутливості відбувалося значно швидше, ніж збільшення сили м'язів та обсягу рухів, тому покращення провідності нерва характеризувалося не тільки збільшенням сили м'язів, а й підвищенням чутливості в автономній зоні (табл.4).

таблиця 1. Обсяг первинного хірургічного втручання, виконаного з приводу ушкодження нервів верхніх кінцівок

\begin{tabular}{|l|c|c|}
\hline \multirow{2}{*}{ Хірургічна допомога } & \multicolumn{2}{|c|}{ Кількість хворих } \\
\cline { 2 - 3 } & $\mathbf{a 6 c . ~}$ & \% \\
\hline $\begin{array}{l}\text { Первинна хірургічна обробка } \\
\text { (ПХО) та зашивання рани }\end{array}$ & 8 & 5,8 \\
\hline ПХО, первинний шов нерва & 26 & 19,4 \\
\hline $\begin{array}{l}\text { ПХО, первинний шов } \\
\text { сухожиль }\end{array}$ & 4 & 2,98 \\
\hline $\begin{array}{l}\text { ПХО, перев'язування } \\
\text { магістральної судини або шов } \\
\text { ушкодженої стінки судини }\end{array}$ & 30 & 21,6 \\
\hline Невроліз & 64 & 47,8 \\
\hline Металоостеосинтез & 3 & 1,9 \\
\hline Разом & 135 & 100 \\
\hline
\end{tabular}

Таблиця 2. Повторні операції на нервах верхньої кінцівки

\begin{tabular}{|l|c|c|c|c|}
\hline \multirow{2}{*}{ Операція } & \multicolumn{4}{|c|}{ Кількість операцій на нервах } \\
\cline { 2 - 5 } & $\begin{array}{c}\text { Сере- } \\
\text { дин- } \\
\text { ному }\end{array}$ & $\begin{array}{c}\text { ліктьо- } \\
\text { вому }\end{array}$ & $\begin{array}{c}\text { Проме- } \\
\text { невому }\end{array}$ & Разом \\
\hline Нейрорафія & 23 & 15 & 15 & 53 \\
\hline Невроліз & 24 & 15 & 12 & 51 \\
\hline $\begin{array}{l}\text { Зшивання 3 } \\
\text { транспозицією } \\
\text { нерва }\end{array}$ & 3 & 9 & 6 & 18 \\
\hline Аутопластика & 5 & 3 & 2 & 10 \\
\hline $\begin{array}{l}\text { Імплантація } \\
\text { електродів }\end{array}$ & 8 & 6 & 10 & 24 \\
\hline Загалом & 63 & 48 & 45 & 156 \\
\hline
\end{tabular}


таблиця 3. Ступінь відновлення рухових функцій у постраждалих, повторно оперованих на нервах верхньої кінцівки

\begin{tabular}{|l|c|c|c|c|}
\hline \multirow{2}{*}{$\begin{array}{c}\text { Нерви } \\
\text { верхньої } \\
\text { кінцівки }\end{array}$} & \multicolumn{3}{|c|}{ Ступінь відновлення } \\
\cline { 2 - 5 } & хороше & $\begin{array}{c}\text { задо- } \\
\text { вільне }\end{array}$ & $\begin{array}{c}\text { відсут- } \\
\text { ність } \\
\text { ефекту }\end{array}$ & разом \\
\hline Променевий & 24 & 12 & 3 & 39 \\
\hline Ліктьовий & 27 & 12 & 6 & 45 \\
\hline Серединний & 33 & 6 & 12 & 51 \\
\hline Загалом, абс. & 84 & 30 & 21 & 135 \\
\hline$\%$ & 62,2 & 22,2 & 15,6 & 100 \\
\hline
\end{tabular}

Таблиця 4. Ступінь відновлення чутливості у постраждалих, повторно оперованих на нервових стовбурах верхньої кінцівки

\begin{tabular}{|l|c|c|c|c|}
\hline \multirow{2}{*}{$\begin{array}{c}\text { Нерви } \\
\text { верхньої } \\
\text { кінцівки }\end{array}$} & \multicolumn{4}{|c|}{ Ступінь відновлення } \\
\cline { 2 - 5 } хороше & $\begin{array}{c}\text { задо- } \\
\text { вільне }\end{array}$ & $\begin{array}{c}\text { відсут- } \\
\text { ність } \\
\text { ефекту }\end{array}$ & разом \\
\hline Променевий & 14 & 22 & 6 & 42 \\
\hline Ліктьовий & 9 & 27 & 6 & 42 \\
\hline Серединний & 11 & 33 & 7 & 51 \\
\hline Загалом, абс. & 34 & 82 & 19 & 135 \\
\hline$\%$ & 25,2 & 60,7 & 14,0 & 100 \\
\hline
\end{tabular}

Достовірність отриманих результатів оцінювали за методом Вілкоксона-Манна-Уїтні непараметричних критеріїв статистики. Різниця показників рухів та чутливості до і після лікування достовірно $(\mathrm{P}<0,001$, $\mathrm{r}=0,66)$. Коефіцієнт достовірності ступеню відновлення рухів та чутливості підтверджує ефективність застосування мікрохірургічних методів та тривалої електростимуляції для більш повного відновлення функції м'язів, покращення чутливості та регресу больового синдрому, що в цілому сприяє зменшенню тривалості лікування та соціальної реабілітації пацієнтів.

Встановлений кореляційний зв'язок між строками госпіталізації хворих для повторного оперативного втручання та його результатом ( $\mathrm{P}<0,05, \mathrm{r}=0,698)$.

Висновки. 1. Вирішальне значення у поліпшенні результатів хірургічного лікування ушкоджень пе- риферичних нервів має проведення НФ моніторингу процесу регенерації нервів після операції, а при виявленні значної затримки чи відсутності реіннерваційного процесу - виконанання повторного оперативного втручання.

2. Отримані дані свідчать про доцільність виконання повторних оперативних втручань на нервових стовбурах для досягнення корисного обсягу рухів у верхній кінцівці.

3. На основі результатів комплексного клінічного обстеження, аналізу причин (недоліки діагностики, дефекти хірургічної техніки, порушення умов у реабілітаційний період) незадовільного результату раніше виконаного оперативного втручання, а також даних клініко-нейрофізіологічного дослідження можна обґрунтувати показання до диференційованого повторного оперативного втручання.

\section{Список літератури}

1. Flores A.J. Anatomy and physiology of peripheral nerve injury and repair / A.J.Flores, C.J. Lavernia, P.W. Owens // Am. J. Orthop.- 2000. - V.29, N3.- P.167-173.

2. Lee H.J. Manual of nerve conduction study and surface anatomy for needle electromyography / H.J.Lee, J.A.DeLisa. - Philadelphia: Lippincott Williams \& Wilkins, 2005. - 4th ed. $-294 \mathrm{p}$.

3. Чеботарьова Л.Л. Застосування клініко-електрофізіологічних методів дослідження на етапах лікування травматичного пошкодження лицевого нерва / Л.Л.Чеботарьова, А.І.Третьякова // Укр. нейрохірург. журн. - 2003. - №3. - C.54-60.

4. Берстнев В.П. Диагностика и хирургическое лечение повреждений нервов конечностей: автореф. дис. ... д-ра мед.наук / В.П. Берстнев - Л., 1986. - 36 с.

5. Кардаш А.М. Восстановительное хирургическое лечение больных с травматическими повреждениями нервов: автореф. дис. ...д-ра мед. наук / А.М. Кардаш. - К., 2010.-18 c.

6. Сулий Н.Н. Дифференцированное микрохирургическое лечение повреждения плечевого сплетения: автореф. дис. ... д-ра мед. наук /Н.Н. Сулий. - К., 1999.- 28 с.

7. Касаткина Л.Ф. Электромиографические методы иссле дования в диагностике нервно-мышечных заболеваний. Игольчатая электромиография/ Л.Ф. Касаткина, О.В. Гильванова. - М.: Медика, 2010. - 416 с

8. Чеботарева Л.Л. Комплексная диагностика травматических повреждений плечевого сплетения и периферических нервов и контроль восстановления их функции: автореф. дис. ...д-ра мед. наук:14.01.05/ Л.Л. Чеботарева. - K.,1998. -32 c. 


\section{Татарчук М.M.}

Отделение восстановительной нейрохирургии, Институт нейрохирургии им. акад. А.П. Ромоданова НАМН Украины, Киев, Украина

\section{Повторные операции при травме периферических нервов верхней конечности}

Вступление. Повторные операции - наименее изученный раздел хирургии периферических нервов.

Материалы и методы. Проанализированы результаты лечения 135 больных, которым проведено повторное хирургическое вмешательство на нервах верхних конечностей. Использовали клиниконеврологический, нейровизуализирующие и нейрофизиологические (НФ) методы исследования, в том числе электронейромиографию (ЭНМГ) и внутримышечную игольчатую электромиографию (ЭМГ).

Результаты. У 135 больных выявлено повреждение 156 нервов. Повторные операции, выполненные в поздние сроки после первой операции, имеют ряд особенностей. По степени восстановления двигательной функции хорошие и удовлетворительные результаты достигнуты у 114 (84,4\%) повторно оперированных больных. Хорошая и удовлетворительная степень восстановления чувствительности отмечена у 116 (75,9\%) пострадавших, повторно оперированных на нервах верхней конечности.

Выводы. 1. Клинико-нейрофизиологический мониторинг процессов регенерации периферических нервов позволяет определить дальнейшую тактику лечения. 2. Проведение повторного хирургического вмешательства при травме периферических нервов улучшает нейро-моторную функцию верхней конечности.

Ключевые слова: травма периферических нервов верхней конечности, повторные операции, нейрофизиологический мониторинг регенерации.

Поступила в редакцию 26.02.13. Принята к публикации 06.03.13.

Адрес для переписки: Татарчук Михаил Михайлович, Отделение восстановительной нейрохирургии, Институт нейрохирургии им. акад. А.П. Ромоданова, ул. Платона Майбороды, 32, Киев, Украина, 04050, e-mail: MTatarchuk@ ukr.net

\section{Tatarchuk M.M.}

Restorative Neurosurgery Department, Institut of Neurosurgery named after acad. A.P.Romodanov, NAMS Ukraine, Kiev, Ukraine

\section{Injury of peripheral nerves: secondary surgeries}

Introduction. Secondary surgery is the one of less studied chapters of surgery of peripheral nerves.

Materials and methods. This study summarizes the results of secondary surgeries of 135 patients with injuries of upper extremity peripheral nerves. To evaluate the outcomes we utilized neurological examination, EMG and MRI studies.

Results. 156 injuries of peripheral nerves were present in 135 patients. Secondary surgeries which have been performed in late terms after primary surgery have several particular qualities. After secondary surgery we obtained moderate and good restoration of motion in 114 (84.4\%) patients, moderate and good restoration of sensitivity in $116(75.9 \%)$ patients.

Conclusions. Clinical and EMG monitoring of regeneration of peripheral nerves allows practitioner to define further tactics of treatment. Secondary surgery at injury of peripheral nerves improves functioning of upper extremity.

Key words: injury of peripheral nerves, secondary surgery, EMG regeneration monitoring.

Received, February 26, 2013. Accepted, March 06, 2013.

Address for correspondence: Michael Tatarchuk, Restorative Neurosurgery Department, Institute of Neurosurgery named after acad. A.P. Romodanov, 32 Platona Mayborody St, Kiev, Ukraine, 04050, e-mail: MTatarchuk@ukr.net 